\title{
STRUCTURAL ANALYSIS OF TOURISM COMPANIES IN THE SOUTH-EAST DEVELOPMENT REGION, ROMANIA
}

DOI: http://dx.doi.org/10.18509/GBP.2020.71

UDC: 338.486.2:005.52]:303.71(498-12)"2000/2018"

\author{
Joița Oana Elena ${ }^{1,2}$ \\ Tufănoiu Ionuț ${ }^{1,2}$ \\ Simion Alina ${ }^{1,2}$ \\ Grecu Alexandra ${ }^{1,2}$ \\ Drăghici Cristian Constantin ${ }^{1,2}$ \\ ${ }^{1}$ Research Center for Integrated Analysis and Territorial Management, \\ University of Bucharest, Romania \\ ${ }^{2}$ Faculty of Geography, University of Bucharest, Bucharest, Romania
}

\begin{abstract}
The development of the tourism sector can stimulate economic growth and contribute to mitigating the existing imbalances at regional level, also representing an important source of income growth for the population. Thus, the analysis of the main economic indicators in the tourism sector considered to be relevant (number of companies, number of employees, turnover and profit) becomes a necessity, they can provide relevant information that could be used in drawing up future development strategies where tourism plays an important role.

From this perspective, in the present study we proposed the structural analysis of a single economic indicator, namely tourism companies in the South-East Development Region. This analysis aimed to identify those economic sectors of tourism characterized by a positive dynamic, sectors that could dynamize the evolution of local economies. In order to reach the goal, a database was created for the period 2000-2018, at the 4-digit NACE code level (Classification of Activities in the National Economy), regarding the number and structure of tourism companies for the South-East Development Region. The database was subsequently used for graphical and cartographic representations, both evolutionarily and territorially for the analyzed indicator.

The obtained results show that the structural analysis of the tourism companies can provide us relevant information, regarding the viability of the tourism sector, both at territorial level and from an evolutionary and structural perspective.
\end{abstract}

Keywords: structural analysis, companies, tourism, entrepreneurship, South-East Development Region

\section{INTRODUCTION}

At EU level, entrepreneurship benefits from important support because it is considered that the development of a country and the economic growth, which is reflected in the increase of the standard of living of the population, can be determined by the dynamics, the volume and the quality of the investments made [1], [2], [3]. In recent years, one of the economic sectors in which much has been invested is tourism. The investments in the tourism field represent an energizing factor from the economic and social point of view, since they have a major contribution to the GDP, reduces unemployment by generating jobs, developing infrastructure, and through the multiplier effect plays an important role 
in the sustainable development of a country or region [4], [5], [6], [7], [8], [9]. The variety of natural and anthropic resources, from the studied region, represents a potential that can be exploited by the regional economy through a large number of investments in the tourism field, with numerous economic and social benefits at local and regional level. Therefore, the entrepreneurial sector is considered a real engine of territorial systems development [10], [11], [12], [13]. By analyzing the number of companies, we can obtain information about the tourism development of a region and we can identify development patterns and trends, which will help us to set the objectives for the elaboration of integrated development strategies at local and regional level [14], [15].

\section{METHODOLOGY}

The South-East Development Region is the second largest in size and one of the most attractive regions in Romania, from a tourist point of view, through the variety of relief forms and the numerous natural and cultural resources with tourist potential. The presence within the Danube Delta region, the only delta in the world declared a reserve of the biosphere and the Black Sea coast, is only a part of the important resources that can be used by the regional economy. (Figure 1).

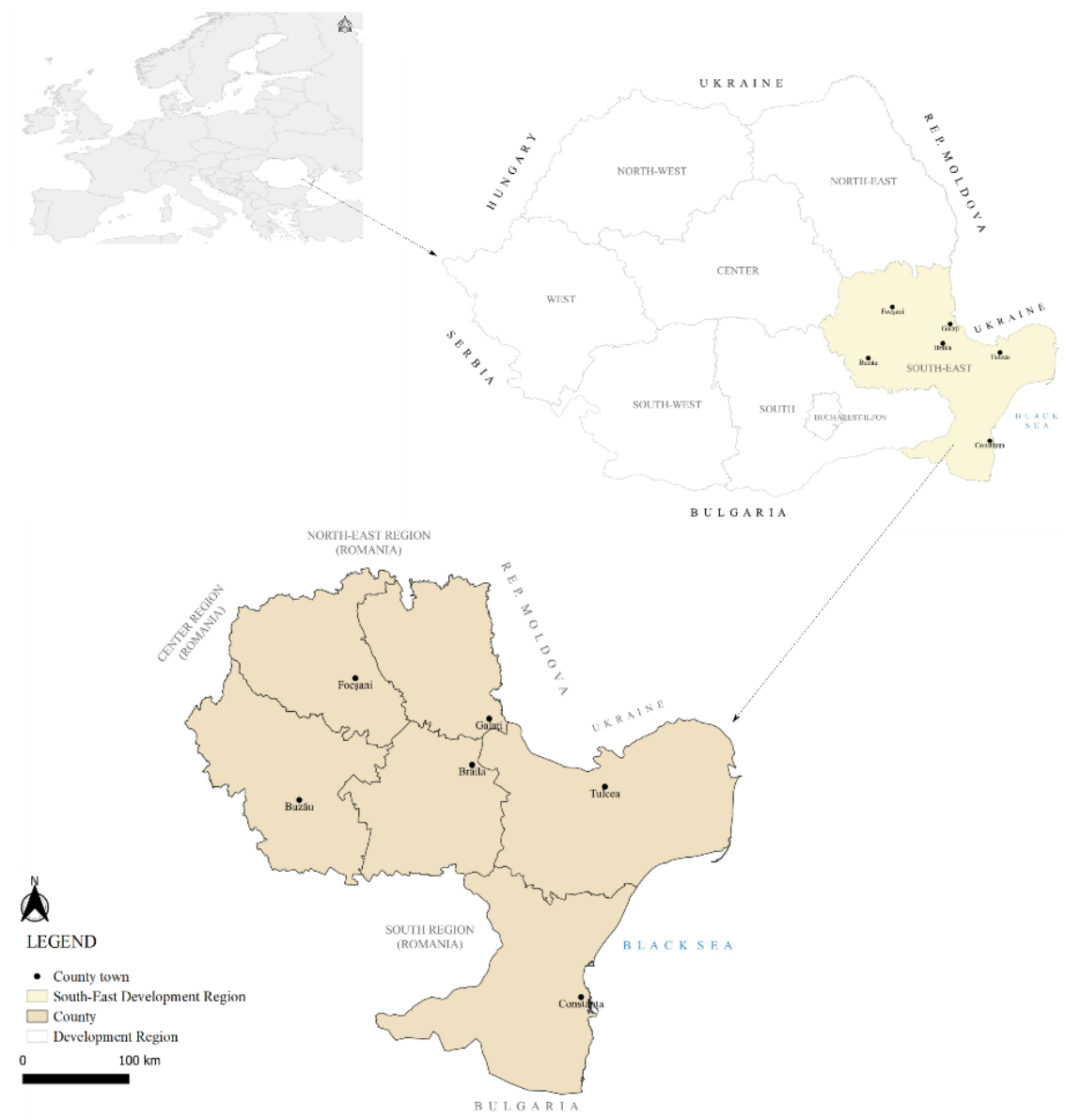

Figure 1. Study area - The South-East Development Region

In order to carry out the structural analysis of the companies that carry out tourist activities, a database has been created at four-digit NACE codes (Classification of Activities in the National Economy), regarding the number and structure of tourism 
companies in the South-East Development Region, for the period 2000-2018. Thus, a number of 10 NACE codes were selected corresponding to the activities in the tourism sphere:

5510

Hotels and similar accommodation

5520

Holiday and other short-stay accommodation

$5530 \quad$ Camping grounds, recreational vehicle parks and trailer parks

$5590 \quad$ Other accommodation

7911 Travel agency activities

7912 Tour operator activities

7990 Other reservation service and related activities

$9102 \quad$ Museums activities

9103 Operation of historical sites and buildings and similar visitor attractions

9104 Botanical and zoological gardens and nature reserves activities

With the help of the database, graphical representations were made from an evolutionary point of view for the analyzed indicator.

\section{RESULTS}

From the analysis of the graphs in Figure 2, it can be noted the evolution of the total number of companies in parallel with the evolution of the number of companies with activities specific to the tourism field, in the South-East Development Region, for the period 2000-2018. Between 2000-2008, the total number of companies increased by more than $180 \%$, from 23843 to 67248 (Figure 2A). In 2008-2010, due to the economic crisis, the total number of companies decreased to 63857, disappearing altogether, over 3300 companies. In 2011, the total number of companies registered an increase of over 4500 companies, so that, a year later, it would decrease again. Starting with 2013 , the total number of companies remains around 67000, with a slight increase to 68823 companies in 2017, as in 2018 their number will decrease to 67596 companies. The share of tourism companies in the total number of companies varies from $1.7 \%$, in the year 2000 , to $2.5 \%$, in 2018, increasing steadily throughout the studied time interval.

The number of companies that carry out tourist activities, in the studied region, gradually increases, from 415, in 2000, to 1694, in 2018 (Figure 2B). It is noted that in the period 2000-2008 the number of tourism companies increased rapidly, in 2001 and 2002 registering with more than $20 \%$ more companies than in the previous year. In 2009 there were 1370 companies, the increase compared to 2000 being about $230 \%$. During the economic crisis, the number of companies with tourist activities decreased by only $0.5 \%$, in 2010 compared to 2009 and in 2012 compared to 2011. Starting with 2013, the number of companies is starting to grow again, but at a slower pace. If in the period 2013-2016 the annual registered increases did not exceed 2\%, in 2017 the number of tourism companies increased by more than $7 \%$ compared to 2016, in 2018 to increase by only $1.3 \%$.

From the analysis of Figure 3, it can be observed that a positive dynamic was registered at NACE 5510 code level, the number of hotels in the studied region increasing from 217 , in 2000, to 548 in 2018. During the period studied, the number of hotels increased rapidly until 2009, when it reached a number of 492 hotels, after which, growth grew at a slower pace, with short periods of decline. The same positive dynamics was also recorded at NACE code 5520, where a significant increase in the number of accommodation facilities can be observed from 28 in 2000, to 470 in 2018. The number of camping grounds, recreational vehicle parks and trailer parks (5530 NACE code), does not know important 
variations during the period studied. If in 2000, their number was 18, in 2018 it reaches 37. Other accommodation services (5590 NACE code) increase in number from 50 to 227 , between 2000-2008, and then decrease or increase slightly.
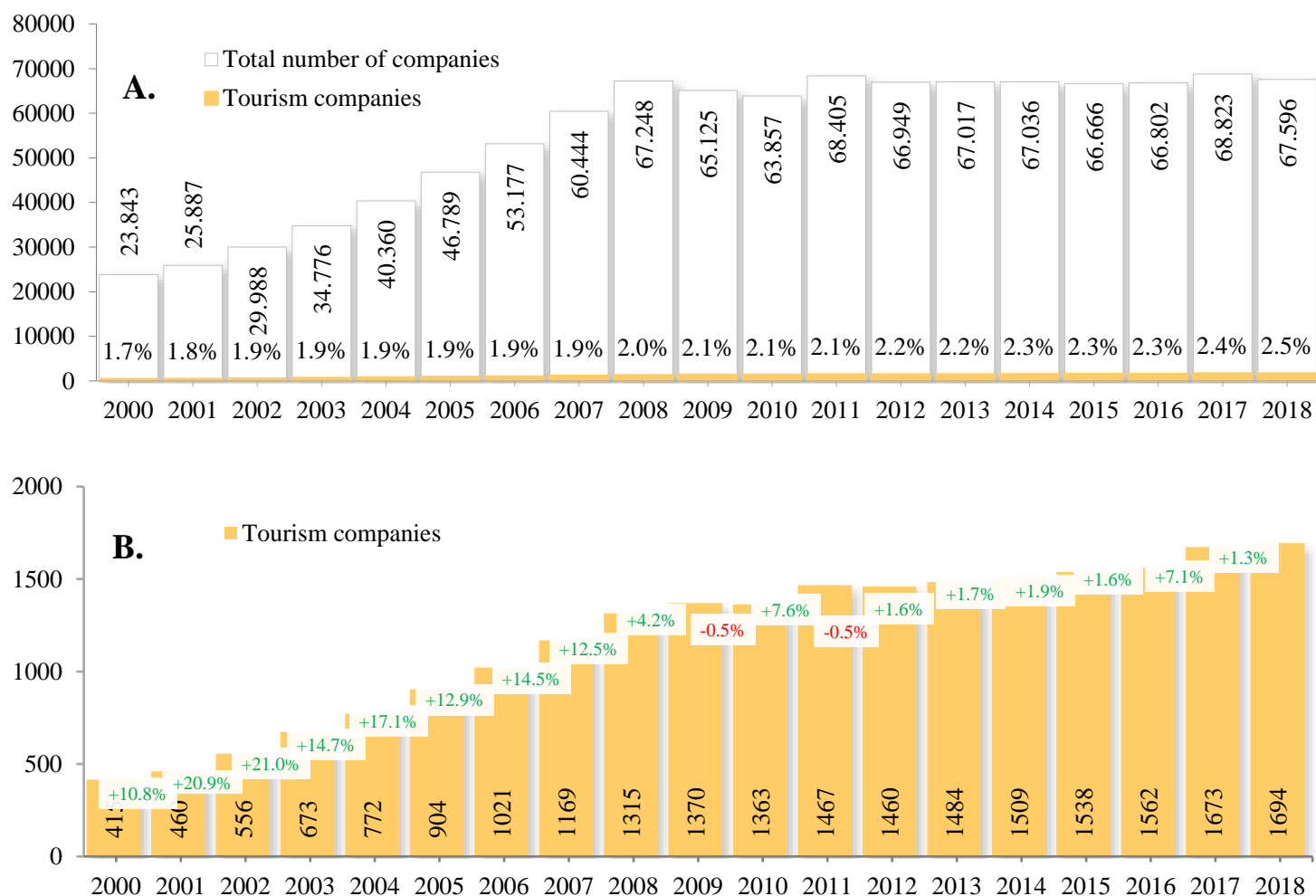

Figure 2. A. Evolution of the total number of companies in the administrative-territorial units with tourism sector in the South-East Development Region, Romania and the share of tourism

B. Evolution of the number of tourism companies from the administrative-territorial units with tourism sector in the South-East Development Region, Romania Source: Project UB 1423

The highest value was registered in 2017, when it reached a number of 234 companies. The travel agencies (7911 NACE code), also registered a positive dynamic, between 2000 and 2018. If, in 2000, in the South-East Development Region, there were 62 companies with this profile, in 2009, their number reached 272. Regarding tour operators field (7912 NACE code), their number increases from 34, in 2000, to 146, in 2011, after which, it slightly decreases to 139 , in 2012, so that in 2013-2014 it will increase to 163 companies. Since 2015, the number of tour operators has decreased, reaching 140 companies, in 2018. For the 7990 NACE code, we can observe an increase in the number of companies from 2000 to 2009, from 6 to 32 companies, after which, their number varies between 27 (2010 and 2015) and 35 (2017). In 2018, there were 34 companies with this profile. In the studied region, between 2000-2007, no company with a museum activity worked (9102 NACE code). In the database, there are 2 such companies registered in 2008 and in 2011, so that during the time period 2009-2015, only one company with this profile operates. Companies that manage monuments and historic buildings (9103 NACE code) are also in a small number. In the studied region, only one company with Botanical and zoological gardens and nature reserves activities (9104 NACE code) has been operating since 2012. Analyzing the share of each Nace code in the total tourism companies (Figure 4), from the South-East Development Region, for six years selected from the analyzed period, it can be observed that the highest share, for each year, is held by the number of companies 
from the hotel field (5510 NACE code). Also, the share of hotels, in the total number of companies in the tourism field, is decreasing from $52 \%$, in 2000 , to $33 \%$, in 2018 . On the second place, as a share in the number of companies with tourist activity, the travel agencies are located (NACE code 7911), between 2000-2013, yielding the place, in 2018, for companies with accommodation facilities for holidays and short periods (NACE code 5520). If the travel agencies vary as a percentage between 14\% (2018) and 20\% (20082009), the companies that correspond to the CAEN code 5520 know a continuous increase from $7-9 \%$, in the years 2000 and 2004 respectively, at $11-13 \%$, in $2008-2009$, up to $28 \%$, in 2018 .

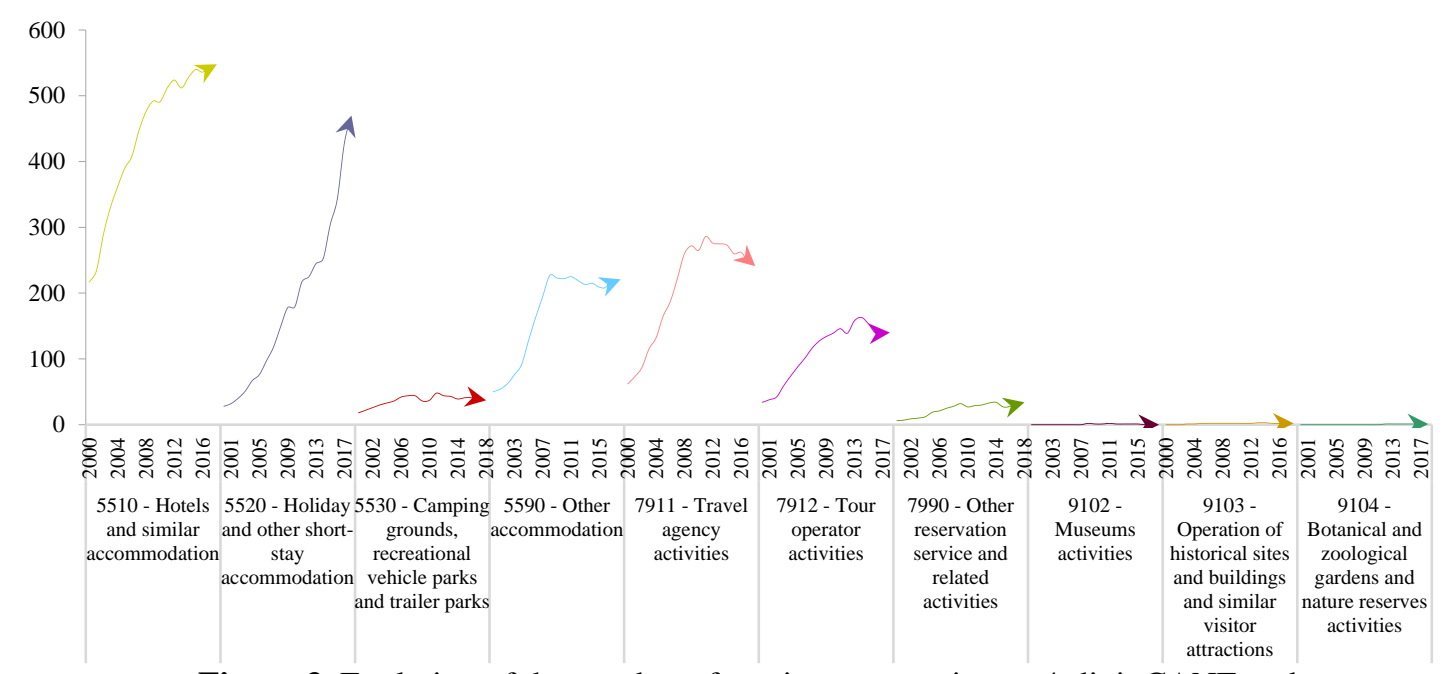

Figure 3. Evolution of the number of tourism companies on 4-digit CANE codes Source: Project UB 1423

Camping grounds, recreational vehicle parks and trailer parks (NACE code 5530), which owned 4\% of the total number of tourism companies in the years 2000, 2004 and 2008, gradually decreased, reaching a share of $2 \%$, in 2018. Firms offering other accommodation services (NACE code 5590) had a share of 12\%, in 2000 and 2004, reaching $17 \%$, in 2008, respectively $16 \%$, in 2009, and then decreasing to $13 \%$, in 2018 . For the reference years, it is observed that $t$ Tour operator activities (NACE code 7912), slightly increase from $8 \%$, in 2000, to $10 \%$ in 2004, 2008 and 2009, reaching $11 \%$, in 2013 , after which it decreased, again, at $8 \%$, in 2018. A constant share of $2 \%$ is held by the number of companies with other reservation service and related activities (NACE code 7990), the rest of the companies with museums activities, operation of historical sites and buildings and similar visitor attractions and botanical and zoological gardens and nature reserves activities have a share of $0 \%$. 
2000

2008

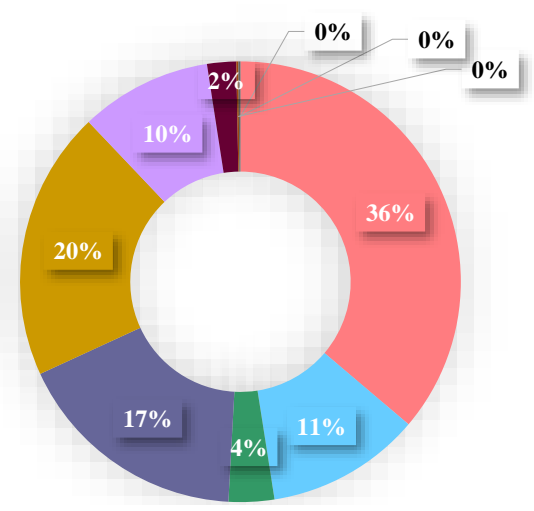

2013

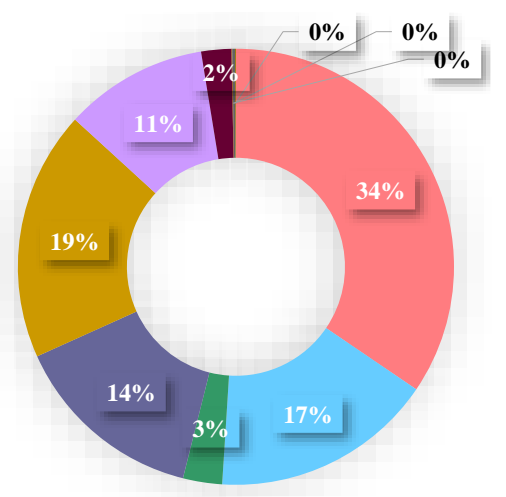

2004

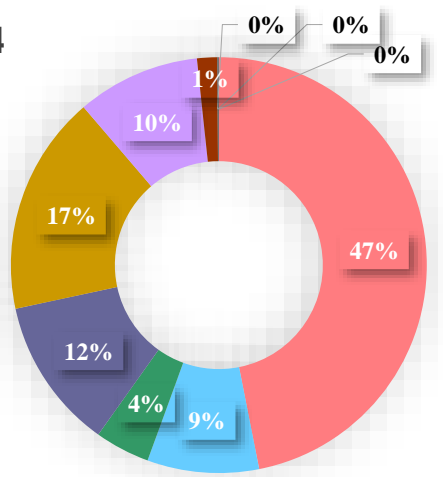

2009
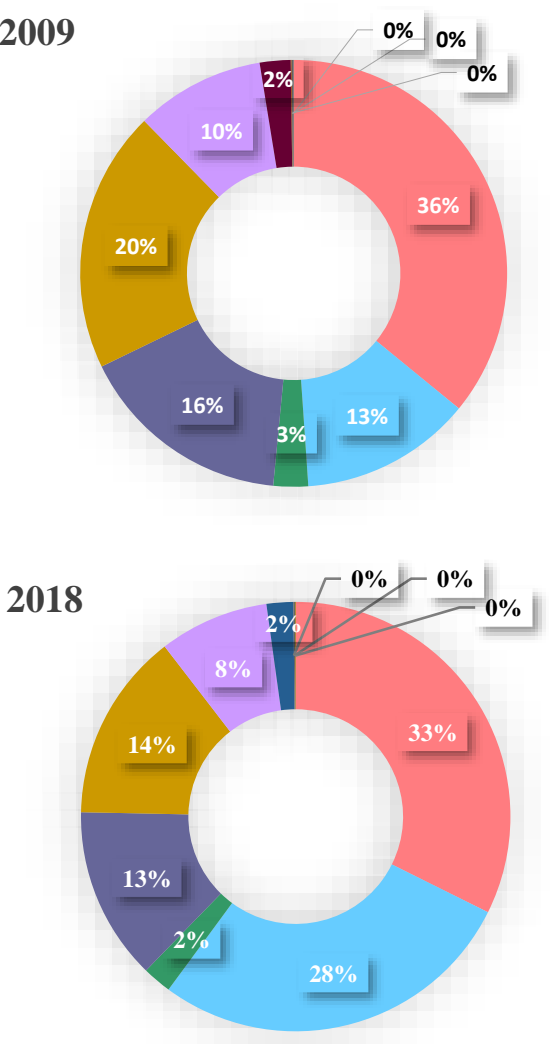

5510 - Hotels and similar accommodation

5520 - Holiday and other short-stay accommodation

$\square 530$ - Camping grounds, recreational vehicle parks and trailer parks

5590 - Other accommodation

7911 - Travel agency activities

7912 - Tour operator activities

- 7990 - Other reservation service and related activities

9102 - Museums activities

घ103 - Operation of historical sites and buildings and similar visitor attractions

n 9104 - Botanical and zoological gardens and nature reserves activities

Figure 4. Share of each NACE code from tourism in total tourism companies Source: Project UB 1423 


\section{CONCLUSIONS}

Following the structural analysis and the evolution of the number of companies that carry out tourism activities in the South-East Development Region, between 2000-2018, the following are highlighted:

- during the period studied, the entrepreneurship in tourism has developed continuously, the number of companies increasing greatly;

- the share of tourism companies, in the total number of companies in the studied region, increased from $1.7 \%$ to $2.5 \%$;

- the evolution of tourism companies, based on four-digit NACE codes, shows a positive dynamic for codes 5510, 5520, 5590, 7911 and 7912;

- regarding the share of NACE codes in the total number of tourism companies, it is observed that although the number of companies with hotel activities is increasing, their share is decreasing due to the increase of the number of companies that carry out other tourism activities..

The elaboration of efficient management strategies, regarding the development of the economic activities at the local level, cannot be realized without a deep knowledge of the way in which the different systemic components specific to the local economy interact [3], [16], [17], [18], [19].

\section{REFERENCES}

[1] Nica E., Sima V., Gheorghe I., Drugau-Constantin A. \& Mirica (Dumitrescu) C.O. Analysis of Regional Disparities in Romania from an Entrepreneurial Perspective, Sustainability, vol. 10, 3450, 2018.

[2] Dan M.C. \& Popescu C. Entrepreneurship in the rural areas of Romania. The impact of the 2007-2013 EU funding programmes, Proceedings of the 11th International Conference on Business Excellence, PICBE, Romania, vol. 11, pp 1129-1136, 2017.

[3] Pintilii R. D., Andronache I., Diaconu D. C., Dobrea R. C., Zelenakova M., Fensholt R., Peptenatu D., Draghici C. C. \& Ciobotaru A. M. Using Fractal Analysis in Modeling the Dynamics of Forest Areas and Economic Impact Assessment: Maramures County, Romania, as a Case Study, Forests, vol. 8, 2017.

[4] Linares L.H., García Betancourt M.E. \& Falcón R.M.C. Sostenibilidad y desarrollo local: procedimiento para la evaluación integrada de los destinos turísticos, Rosa dos Ventos - Turismo e Hospitalidade, vol. 11, pp 84-102, 2019.

[5] Ren T., Can M., Paramati S.R., Fang J. \& Wu W. The impact of tourism quality on economic development and environment: Evidence from Mediterranean Countries, Sustainability, vol. 11, 2296, 2019.

[6] Toselli C.Turismo, patrimonio cultural y desarrollo local. Evaluacion del potencial turistico de aldeas rurales en la provincia de Entre Rios, Argentina, PASOS - Revista de turismo y patrimonio cultural, Spain, vol. 17 (2), pp. 343-361, 2019.

[7] Grecu A., Gruia A.K., Marin M., Bănuță M., Olteanu C., Constantin I., Gadoiu M., Teodorescu C., Dobrea C.R. \& Drăghici C.C. Specificity of Sustainable Structural Dynamics of Local Economy in Romanian Tourist Resorts, Sustainability, vol. 11, 7155, 2019.

[8] Aleksandrov I., \& Fedorova M. Strategic planning of the tourism development in small cities and rural territories as a tool for the development of the regional economy

MATEC Web of Conferences, France, vol. 170, 01011, 2018.

[9] Drăghici, C.C., Pintilii R.D., Peptenatu D., Comănescu L.G., Sirodoev I. The Role of SPA Tourism in the Development of Local Economies from Romania, 2nd Global Conference on 
Business, Economics, Management and Tourism (BEMTUR), Czech Republic, vol. 23, pag 15731577, 2015.

[10] Marin M., Gruia A.K., Grecu A., Dima C. \& Dobrea C.R. Creative economies role in sustainable development of local economies in Central Region - Romania, Proceedings of the Conference Public recreation and landscape protection - with sense hand in hand..., Czech Republic, pp 78-83, 2019.

[11] Pintilii R.D., Peptenatu D., Ciobotaru A.M., Toma S.G., Grigore A.M., Drăghici C.C., Dobrea R.C., Simion A.G. Andronache I., Teodoresc C. \& Diaconu D.C. Creative economies in Romania - spatial projections and trends, Bulletin of Geography-Socio-Economic, vol 37, pp 95108, 2017.

[12] Pintilii R.D., Peptenatu D., Draghici C., Irina S. \& Stoian R.,D. Structural Changes in The Entrepreneurial Profile of The Creative Industries in Romania, Proceedings of the 2nd Global Conference on Economics, Management and Tourism (BEMTUR), Czech Republic, vol. 23, pp 1147-1151, 2015.

[13] Krueger N.\& Brazeal D.V. Entrepreneurial potential and potential entrepreneur, Entrepreneurship Theory and Practice, U.S.A., vol. 18(3), pp 91-104, 1994.

[14] Kinash I.P., Arkhypova L.M., Polyanska A.S., Dzoba O.G., Andrusiv U.Y. \& Iuras I. Economic evaluation of tourism infrastructure development in Ukraine, International Conference on Applied Sciences, Bosnia and Herzegovina, IOP Conference series: Materials Science and Engineering, vol. 477, 012020, 2019.

[15] Arionesei G., Hapenciuc C.V. \& Costea M. Statistical confrontation of the evolution of tourism in the north east region in comparison with the other regions of Romania, Amfiteatru economic, Romania, vol. 18(10), pp. 798-814, 2016.

[16] Prăvălie R., Sîrodoev I., Patriche C.V., Bandoc G., \& Peptenatu D. The analysis of the relationship between climatic water deficit and corn agricultural productivity in the Dobrogea plateau, Carpathian Journal of Earth and Environmental Sciences, vol. 9, pp 201-2014, 2014.

[17] Pintilii R.D., Andronache I., Simion A.G., Drăghici C.C., Peptenatu D., Ciobotaru A.M., Dobrea R.C. \& Papuc R.M. Determining forest fund evolution by fractal analysis (SuceavaRomania), Urbanism Architecture Constructions, vol. 7, pp 31-42, 2016.

[18] Prăvălie R., Patriche C. V., Sîrodoev I., Bandoc G., Dumitraşcu M. \& Peptenatu D. Water deficit and corn productivity during the post-socialist period. Case study: Southern Oltenia drylands, Romania, Arid Land Research and Management, vol. 30, pp 239-257, 2016

[19] Popa, M.C., Peptenatu, D., Drăghici, C.C. \& Diaconu, D.C. Flood Hazard Mapping Using the Flood and Flash-Flood Potential Index in the Buzău River Catchment, Romania, Water, vol. 11, 2116, 2019. 